\title{
Heterosis for post harvest and nutritional quality traits in tomato (Solanum lycopersicum L.)
}

\author{
Rakesh Kumar $^{1 *}$, H. R. Sharma ${ }^{1}$ and Manish Kumar \\ ${ }^{1}$ Dr YS Parmar University of Horticulture and Forestry, Nauni-Solan-173230 ( Himachal Pradesh), INDIA \\ *Corresponding author. E-mail: rakeshuhfsolan@gmail.com
}

Received: January 25, 2016; Revised received: June 4, 2016; Accepted: November 2, 2016

\begin{abstract}
A study was conducted in tomato using an $6 \times 6$ diallel crossing design excluding reciprocals to quantify the magnitude of heterosis and to identify the best heterotic combinations for post harvest and nutritional quality attributes viz. pericarp thickness $(\mathrm{mm})$, fruit firmness $\left(\mathrm{g} / 0.503 \mathrm{~cm}^{2}\right)$, shelf life (days), total soluble solids ( ${ }^{\circ}$ Brix), lycopene content $(\mathrm{mg} / 100 \mathrm{~g})$ and ascorbic acid $(\mathrm{mg} / 100 \mathrm{~g})$ which are considered essential in present day hybrid varieties of tomato from consumer point of view. All the 22 entries (6 parents, $15 F_{1}$ hybrids and 1 standard check) were field evaluated using randomized complete block design with three replications during Kharif 2015-16. Highly significant heterosis ( $5 \%$ level of significance) of positive nature was found for pericarp thickness $(22.90 \%, 32.20 \%$ and $5.62 \%)$, fruit firmness $(17.32 \%, 56.72 \%$ and $9.21 \%)$, shelf life $(17.54 \%, 24.87 \%$ and $9.57 \%)$, total soluble solids $(24.44 \%, 51.44 \%$ and $34.20 \%)$, lycopene content $(28.75 \%, 35.05 \%$ and $25.63 \%)$ and ascorbic acid $(19.07 \%$, $30.00 \%$ and $17.85 \%)$ over the better, mid and standard check, respectively. Three promising crosses viz., Solan Lalima x EC-1055, Solan Lalima x EC-1057 and Solan Lalima x EC-1058 were identified as high yielding $F_{1}$ combinations having superiority to post harvest and nutritional quality traits in tomato and can be promoted for release and commercial cultivation.
\end{abstract}

Keywords: Diallel, Heterosis, Nutritional quality, Solanum lycopersicum L

\section{INTRODUCTION}

Tomato (Solanum lycopersicum L.) is a famous commercial vegetable worldwide for its nutritional value and plays an important role in human daily diet and regarded as health food (Willcox et al., 2003). DeCandolle (1886) advanced the Peruvian hypothesis for the centre of origin of tomato. In world, production of tomato was around 163 million tons from an area of about 4.8 million ha with $33.9 \mathrm{t} /$ ha productivity. India ranks second in production of tomato in the world with 18.73 million tons annual production over an area of 0.88 million ha and $21.2 \mathrm{t} /$ ha productivity (Anonymous, 2014).

On an average, one tomato supplies around 20 per cent of the vitamin A of daily requirements of a man, 40 per cent of vitamin $\mathrm{C}$, as well as supply minerals like potassium, calcium, iron, magnesium, thiamine, riboflavin and niacin. Tomatoes are low in calories i.e. about 35 calories/fruit (FAO, 1979). Tomato is rich in antioxidants like lycopene, ascorbic acid, etc. which reduces risk of a various cancers (Giovanelli et al., 1999). Tomato products contain similar amounts of potassium and folate compared with other popular vegetables, but tomato products are a superior source of alpha-tocopherol and vitamin C (USDA, 2016). In comparison with the other regularly consumed vegetables, only carrots are a better dietary source of vitamin A than tomato-based foods. Nutritional quality of to- mato fruits is of utmost importance to both fresh market and processing industries. Post harvest product quality depends entirely on pre harvest factors and that could be therefore maintained during processing, but not improved by postharvest technologies. This can be achieved by bringing genetic improvement and selecting genotypes with better keeping and nutritional quality when harvested at proper maturity (Ramakrishnan et al., 2010).

The tomato fruit quality can be enhanced to a considerable extent by employing various crop improvement methods and one of the most important method is heterosis breeding. The discovery of the phenomenon of heterosis by Shull (1911) laid the foundation of hybrid seed industry and he defined heterosis as "the superiority of heterozygotes with respect to one or more characters in comparison to corresponding homozygotes". Heterosis has been commercially exploited in breeding of various field crops, fruits and vegetables. Hybrid cultivars are developed in those crops in which heterosis expression is more prominent than others to justify the extra cost required to produce hybrid seed. The unusual high heterosis observed in tomato may be attributed to the fact that once it was a highly out crossing crop which later changed to a self pollinated one (Rick, 1969). Heterosis breeding is extensively exploited for genetic improvement of tomato after it was reported by Hedrick and Booth (1907) in this crop. 
Hybrids are preferred over pure line varieties by the farmers and consumers due to uniform and stable marketable fruit yield, better fruit quality traits as well as tolrance to insect-pests, diseases and abiotic stresses. The development of new tomato hybrids with higher yield as well as good keeping and processing quality to meet the everlasting demand of this crop among stakeholders and fruit processing industries is the ultimate goal of tomato breeders in our country. The present study is an attempt to identify the best heterotic combination(s) with improved post harvest and nutritional quality attributes of tomato by crossing six selected parental lines.

\section{MATERIALS AND METHODS}

This study was conducted during Kharif 2014-15 and 2015-16 at research farm of the Department of Vegetable Science, Dr. YS Parmar University of Horticulture and Forestry, Nauni, Solan (Himachal Pradesh). It is located at an altitude of 1276 meters amsl, longitude of $77^{\circ} 11^{\prime} 30^{\prime \prime} \mathrm{E}$ and latitude of $30^{\circ} 52^{\prime} 30^{\prime \prime} \mathrm{N}$. There were six tomato inbred lines in the experimental material viz., Solan Lalima, UHF-55, EC-2798, EC-1055, EC-1057 and EC-1058, which were crossed in diallel (excluding reciprocal) fashion to get $\mathrm{F}_{1} \mathrm{~s}$ and evaluated along with Naveen $2000+$ as standard check. Six parents, fifteen $F_{1}$ hybrids and standard check were field evaluated using Randomized Complete Block Design (RCBD) with three replications. The seedlings were transplanted at a spacing of 90 $\mathrm{cm} \times 30 \mathrm{~cm}$. Recommended cultural practices were followed. The observations were recorded on six post harvest and nutritional quality parameters viz., pericarp thickness $(\mathrm{mm})$, fruit firmness $\left(\mathrm{g} / 0.503 \mathrm{~cm}^{2}\right)$, shelf life (days), total soluble solids ( $\left.{ }^{\mathrm{B}} \mathrm{Brix}\right)$, lycopene content $(\mathrm{mg} / 100 \mathrm{~g})$ and ascorbic acid (mg/100g).

Post harvest quality traits

Pericarp thickness (mm): Pericarp thickness of five randomly taken fruits at second harvest in each entry was measured after cutting the fruits transversely. Measurement was done with Digital Vernier Caliper in millimeters and mean value was worked out.

1.) Fruit firmness $\left(\mathrm{g} / \mathbf{0 . 5 0 3} \mathrm{cm}^{2}\right)$ : Fruit firmness was obtained by use of fruit pressure tester model FT011 manufactured by EFFEGI48011, Afonsine, Italy. Vine ripe fruits at full pink stage were randomly picked and pressure was applied with plunger after peeling a bit of outer skin and recorded in $\left(\mathrm{g} / 0.503 \mathrm{~cm}^{2}\right)$ surface area. Average of ten fruits was taken.

2.) Shelf life (days): Ten ripe fruits of each treatment were kept at room temperature $\left(28 \pm 2^{\circ} \mathrm{C}\right)$ and their firmness was recorded at harvest and subsequently after a gap of two days till the firmness dropped below $500 \mathrm{~g}$ per $0.503 \mathrm{~cm}^{2}$. The rest of the fruits rendered unmarketable were discarded. The number of days were recorded and expressed as shelf life (days) till the fruits remained in marketable condition.

Nutritional quality traits

3.) Total soluble solids ( $\left.{ }^{\mathbf{B}} \mathrm{Brix}\right)$ : The randomly taken ten ripe tomato fruits at second harvest were crushed and their juice was passed through a double layer of fine mesh cheese cloth. A drop of juice was placed on plate of Erma Hand Refrectometer ( 0 to 32 ranges) and the reading was recorded. The mean of ten readings was averaged for each replication of all treatment.

4.) Lycopene content (mg/100g): Lycopene content of ripe tomato fruits was determined according to method described by Ranganna (1995).

5.) Ascorbic acid content (mg/100g): The ascorbic acid content was determined by 2,6- dichlorophenol indophenol visual titration method as described by Ranganna (1995).

Analysis of variance: Mean replicated data of 6 parents, 15 hybrids and 1 standard check of each parameter were subjected to analysis of variance and ANOVA was set as explained by Gomez and Gomez (1983) for diallel mating scheme excluding reciprocals.

Estimations of heterosis: Increase or decrease was measured as the proportion of deviation of $F_{1}$ over better parent (heterobeltiosis), mid parent (relative heterosis) and standard check (standard heterosis) and were calculated using the procedure illustrated by Mather and Jinks (1971). Significance of heterosis was tested at 5\% level of significance for all the characters included in the study.

\section{RESULTS AND DISCUSSION}

The magnitude of heterosis for different characters under study among the hybrid combinations are presented in Table 1 to 3.

\section{Post harvest quality traits}

1.) Pericarp thickness (mm): In Tomato, fruits having high pericarp thickness can withstand long transportation bruising and remain firm for more number of days as compared to thin fleshed fruits. The heterobeltiotic effects ranged from -40.80 per cent to 22.90 per cent being lowest in EC-2798 x EC-1058 and highest in Solan Lalima x EC-1057. Five crosses showed positive heterosis over better parent for pericarp thickness (mm). Seven cross combinations observed to be significantly surpassing the mid parent value being highest in Solan Lalima x EC-1055 (32.20\%), while three crosses viz. Solan Lalima x EC-1055 (5.62\%), Solan Lalima x EC-1057 (5.04\%) and Solan Lalima x EC$1055(4.26 \%)$ showed significant increase over the standard check (Table 1). Positive heterosis over better parent for pericarp thickness has also been reported by Joshi et al. (2005), Sharma and Thakur (2008), Kumari and Sharma (2011) and Graca et al. (2015) in tomato.

2.) Fruit firmness $\left(\mathbf{g} / \mathbf{5 0 3} \mathbf{c m}^{2}\right)$ : Positive heterosis for fruit firmness becomes especially important when resistance during bulk transportation is an issue, independently of the tomato end use. In the present context, fruit firmness is indisputably relevant, since production zones are often remote in relation to trade centers, especially hilly regions where there is opportunity 
Rakesh Kumar et al. / J. Appl. \& Nat. Sci. 8 (4): 1987-1991 (2016)

Table 1. Heterotic response for pericarp thickness $(\mathrm{mm})$ and fruit firmness $\left(\mathrm{g} / 0.503 \mathrm{~cm}^{2}\right)$ in tomato.

\begin{tabular}{lcccccc}
\hline \multirow{2}{*}{ Hybrid combinations } & \multicolumn{3}{c}{ Pericarp thickness $(\mathbf{m m})$} & \multicolumn{2}{c}{ Fruit firmness $\left(\mathbf{g} / \mathbf{0 . 5 0 3} \mathbf{c m}^{2}\right)$} \\
\cline { 2 - 7 } & HB & RH & SH & HB & RH & SH \\
\hline Solan Lalima X UHF-55 & $-17.73^{*}$ & $-11.79^{*}$ & $-32.56^{*}$ & -0.87 & $12.69^{*}$ & -32.43 \\
Solan Lalima X EC-2798 & $-11.20^{*}$ & $-15.58^{*}$ & $-37.02^{*}$ & -3.63 & $6.13^{*}$ & -34.32 \\
Solan Lalima X EC-1055 & $10.32^{*}$ & $32.20^{*}$ & $5.62^{*}$ & 17.32 & $56.72^{*}$ & 9.21 \\
Solan Lalima X EC-1057 & $22.90^{*}$ & $29.67^{*}$ & $5.04^{*}$ & 13.70 & $45.25^{*}$ & 8.76 \\
Solan Lalima X EC-1058 & $18.24^{*}$ & $26.84^{*}$ & $4.26^{*}$ & 14.11 & $32.38^{*}$ & 2.40 \\
UHF-55 X EC-2798 & -0.71 & $6.46^{*}$ & $-18.60^{*}$ & 15.91 & $29.72^{*}$ & -23.79 \\
UHF-55 X EC-1055 & $-15.99^{*}$ & $-2.96^{*}$ & $-19.57^{*}$ & -9.96 & $19.41^{*}$ & -16.18 \\
UHF-55 X EC-1057 & -2.04 & 0.23 & $-16.28^{*}$ & -9.83 & $12.66^{*}$ & -13.75 \\
UHF-55 X EC-1058 & $-3.96^{*}$ & 0.28 & $-15.31^{*}$ & -36.99 & $-28.60^{*}$ & -43.45 \\
EC-2798 X EC-1055 & $-35.63^{*}$ & $-26.05^{*}$ & $-38.37^{*}$ & -24.73 & $-11.78^{*}$ & -29.94 \\
EC-2798 X EC-1057 & $-6.58^{*}$ & $-5.00^{*}$ & $-20.16^{*}$ & 4.97 & $18.36^{*}$ & 0.41 \\
EC-2798 X EC-1058 & $-40.88^{*}$ & $-38.72^{*}$ & $-47.87^{*}$ & -2.50 & 1.67 & -12.51 \\
EC-1055 X EC-1057 & $-2.83^{*}$ & $2.67^{*}$ & $-6.98^{*}$ & 0.76 & $2.13^{*}$ & -3.62 \\
EC-1055 X EC-1058 & 5.87 & $12.88^{*}$ & 1.36 & 9.66 & $9.97^{*}$ & 2.08 \\
EC-1057 X EC-1058 & $7.25^{*}$ & $8.93^{*}$ & $-5.43^{*}$ & 4.32 & $7.64^{*}$ & -0.22 \\
SE(d) & & 0.04 & & & 11.37 & \\
\hline
\end{tabular}

*Significant at $5 \%$ level

Table 2. Heterotic response for shelf life (days) and total soluble solids $\left({ }^{\circ} \mathrm{B}\right)$ in tomato.

\begin{tabular}{|c|c|c|c|c|c|c|}
\hline \multirow{2}{*}{ Hybrid combinations } & \multicolumn{3}{|c|}{ Shelf life (days) } & \multicolumn{3}{|c|}{ Total soluble solids $\left({ }^{0} B\right)$} \\
\hline & HB & RH & SH & HB & RH & SH \\
\hline Solan Lalima X UHF-55 & $-13.15^{*}$ & $-10.59^{*}$ & $-20.24^{*}$ & 6.26 & $10.27^{*}$ & $14.60^{*}$ \\
\hline Solan Lalima X EC-2798 & $-28.95^{*}$ & $-22.53^{*}$ & $-34.75^{*}$ & -1.41 & $11.59^{*}$ & 6.32 \\
\hline Solan Lalima X EC-1055 & $11.49^{*}$ & $24.87^{*}$ & $9.57^{*}$ & $24.44^{*}$ & $51.44^{*}$ & $34.20^{*}$ \\
\hline Solan Lalima X EC-1057 & $17.54^{*}$ & $22.63^{*}$ & $8.78^{*}$ & $14.34^{*}$ & $49.89^{*}$ & $23.31^{*}$ \\
\hline Solan Lalima X EC-1058 & $12.33^{*}$ & $20.00^{*}$ & $7.92^{*}$ & $12.73^{*}$ & $47.68^{*}$ & $21.57^{*}$ \\
\hline UHF-55 X EC-2798 & $-13.59^{*}$ & $-6.97^{*}$ & $-25.18^{*}$ & 0.87 & $13.34^{*}$ & 0.87 \\
\hline UHF-55 X EC-1055 & 4.15 & $18.49^{*}$ & 2.35 & $17.65^{*}$ & $43.11^{*}$ & $17.65^{*}$ \\
\hline UHF-55 X EC-1057 & $5.25^{*}$ & $10.79^{*}$ & -2.59 & $-15.03^{*}$ & $11.99^{*}$ & $-15.03^{*}$ \\
\hline UHF-55 X EC-1058 & $-13.88^{*}$ & $-7.60^{*}$ & $-17.25^{*}$ & $-12.64^{*}$ & $13.15^{*}$ & $-12.64^{*}$ \\
\hline EC-2798 X EC-1055 & $-26.66^{*}$ & $-16.45^{*}$ & $-27.92^{*}$ & $32.68^{*}$ & $41.16^{*}$ & 3.49 \\
\hline EC-2798 X EC-1057 & $-21.02^{*}$ & $-17.28^{*}$ & $-26.90^{*}$ & 8.10 & $24.30^{*}$ & $-15.69^{*}$ \\
\hline EC-2798 X EC-1058 & $-34.61^{*}$ & $-30.42^{*}$ & $-37.18^{*}$ & 0.53 & $16.07^{*}$ & $-16.99^{*}$ \\
\hline EC-1055 X EC-1057 & $5.19^{*}$ & $8.34^{*}$ & 3.37 & -10.48 & -2.08 & $-38.56^{*}$ \\
\hline EC-1055 X EC-1058 & $-5.75^{*}$ & -3.14 & $-7.37^{*}$ & -4.22 & $14.03^{*}$ & $-20.92^{*}$ \\
\hline EC-1057 X EC-1058 & $-9.96^{*}$ & $-8.27^{*}$ & $-13.49^{*}$ & $-21.64^{*}$ & -7.19 & $-35.29^{*}$ \\
\hline $\mathrm{SE}(\mathrm{d})$ & & 0.26 & & & 0.20 & \\
\hline
\end{tabular}

*Significant at $5 \%$ level

Table 3. Heterotic response for lycopene content (mg/100g) and ascorbic acid content (mg/100g) in tomato.

\begin{tabular}{|c|c|c|c|c|c|c|}
\hline \multirow{2}{*}{ Hybrid combinations } & \multicolumn{3}{|c|}{ Lycopene content (mg/100g) } & \multicolumn{3}{|c|}{ Ascorbic acid content (mg/100g) } \\
\hline & HB & RH & SH & HB & RH & SH \\
\hline Solan Lalima X UHF-55 & 0.83 & 2.90 & 2.50 & 6.46 & $10.52^{*}$ & $11.07^{*}$ \\
\hline Solan Lalima X EC-2798 & $-11.52^{*}$ & $-6.20^{*}$ & -3.66 & -1.28 & $8.46^{*}$ & 3.00 \\
\hline Solan Lalima X EC-1055 & $28.75^{*}$ & $32.45^{*}$ & $25.63^{*}$ & $12.96^{*}$ & $32.92^{*}$ & $17.85^{*}$ \\
\hline Solan Lalima X EC-1057 & $7.96^{*}$ & $24.44^{*}$ & $5.34^{*}$ & $7.52^{*}$ & $28.90^{*}$ & $12.18^{*}$ \\
\hline Solan Lalima X EC-1058 & $6.69^{*}$ & $32.21^{*}$ & 4.10 & $8.12^{*}$ & $31.69^{*}$ & $12.80^{*}$ \\
\hline UHF-55 X EC-2798 & $-20.01^{*}$ & $-17.27^{*}$ & $-12.91^{*}$ & -1.55 & 5.43 & -4.82 \\
\hline UHF-55 X EC-1055 & 3.11 & $11.57^{*}$ & $4.82^{*}$ & $9.64^{*}$ & $27.03^{*}$ & 5.99 \\
\hline UHF-55 X EC-1057 & $8.17^{*}$ & $35.05^{*}$ & $9.96^{*}$ & $5.56^{*}$ & $23.40^{*}$ & 2.05 \\
\hline UHF-55 X EC-1058 & $-9.08^{*}$ & $23.28^{*}$ & $-7.57^{*}$ & -1.08 & $16.74^{*}$ & -4.36 \\
\hline EC-2798 X EC-1055 & $-13.41^{*}$ & 4.65 & $-5.72^{*}$ & $19.07^{*}$ & $30.00^{*}$ & -0.13 \\
\hline EC-2798 X EC-1057 & $-39.89^{*}$ & $-12.35^{*}$ & $-34.55^{*}$ & -3.81 & 3.38 & $-19.32^{*}$ \\
\hline EC-2798 X EC-1058 & $-45.07^{*}$ & $-12.44^{*}$ & $-40.19^{*}$ & -5.44 & 1.38 & $-20.68^{*}$ \\
\hline EC-1055 X EC-1057 & 3.78 & $28.51^{*}$ & $-26.01^{*}$ & $-12.06^{*}$ & -5.79 & $-29.22^{*}$ \\
\hline EC-1055 X EC-1058 & $-13.38^{*}$ & $12.73^{*}$ & $-38.25^{*}$ & $10.46^{*}$ & $13.99^{*}$ & $-12.96^{*}$ \\
\hline EC-1057 X EC-1058 & $41.32^{*}$ & $49.43^{*}$ & $-30.48^{*}$ & -1.86 & -0.82 & $-21.01^{*}$ \\
\hline $\mathrm{SE}(\mathrm{d})$ & & 0.11 & & & 1.07 & \\
\hline
\end{tabular}

*Significant at $5 \%$ level 
to grow off season crop of tomato. The heterosis for this trait over better parent ranged from -36.99 per cent to 17.32 per cent, being maximum positive in Solan Lilima x EC-1055, while maximum negative was recorded in UHF-55 x EC-1058. Twelve crosses showed significant increase over mid parent while seven crosses over better parent. Similarly out of fifteen cross combinations, seven showed significant positive increase over standard check and highest increase was observed with Solan Lalima X EC-1055 (Table 1). Garg and Cheema (2011) and Graca et al. (2015) also reported positive heterosis in one and more cross combinations for fruit firmness in tomato.

3.) Shelf life (days): The heterosis over better parent ranged from -34.61 (EC-2798 x EC-1058) to 17.54 percent (Solan Lalima x EC-1057). Five crosses exhibited significant increase over better parent. Standard heterosis ranged from -37.18 percent (EC-2798 x EC1058 ) to 9.57 percent (Solan Lalima $x$ EC-1055) and out of fifteen cross combinations, six surpassed the mid parental value while three crosses showed significant increase over standard check viz. Solan Lalima x EC1055, Solan Lalima x EC-1057 and Solan Lalima x EC1058 (Table 2). Reddy and Reddy (1994) and Premalakshmi et al. (2002) also reported significant positive relative heterosis and heterobeltiosis for shelf life in tomato. Fruits with better shelf life can be stored for prolonged period and are preferred by consumers in the market.

\section{Nutritional quality traits}

4.) Total soluble solids ( ${ }^{0}$ Brix): The total content of soluble solids on fruits (TSS) is a key trait, as it influences final product flavor and consistency, and ultimately determines the final yield after processing. The heterobeltiotic effects of total soluble solids ranged from -21.64 to 32.68 percent, being lowest in EC-1057 x EC-1058 and highest in EC-2798 x EC-1055. Thirteen crosses were superior to mid parental value, five crosses exhibited significant positive heterobeltiosis for total soluble solids and five crosses over standard check (Table 2). Similar results have also been reported by Anita et al. (2005), Kumari and Sharma (2011) and Graca et al. (2015) in tomato. Kumari and Sharma (2011) found five crosses showing significant positive increase over check Naveen $2000+$, the highest increase being in EC- $521051 \mathrm{x}$ Solan Vajr $(11.92 \%)$ for this trait.

5.) Lycopene content (mg/100g): Lycopene is responsible for red color in tomato berries and is one of the most effective antioxidant as it neutralizes free oxygen radicals and destroys peroxide radicals efficiently. The heterosis over better parent for this trait ranged from 45.07 percent to 41.32 percent, being maximum positive in EC-1057 x EC-1058 and maximum negative in EC-2798 x EC-1058. Six crosses exhibited significant positive heterobeltiosis for lycopene content. Whereas out of fifteen cross combinations, nine showed significant positive increase over mid parent, while four crosses over standard check Naveen 2000+ and maximum increase was recorded in Solan Lalima $x$ EC$1055(25.63 \%)$ as shown in Table 3. Droka et al. (2012) also reported significant positive heterosis for lycopene content in few cross combinations of tomato.

6.) Ascorbic acid (mg/100g): Ascorbic acid content is nutritionally an important constituent. Small fruited genotypes are generally richer in ascorbic acid content. The heterosis over better parent ranged from -12.06 percent (EC-1055 x EC-1057) to 19.07 percent (EC$2798 \times$ EC-1055) for this trait. Seven crosses exhibited significant positive heterosis over better parent, ten crosses over mid parent and four crosses showed significant increase over standard check (Table 3). Anita et al. (2005), Singh et al. (2005) and Kumari and Sharma (2011) also found similar results in their studies on tomato crop. Kumari and Sharma (2011) reported heterosis over better parent maximum in EC1914 x EC-15998 (23.49\%) and maximum standard heterosis in Cross EC-13736 x Solan Vajr of 29.47 per cent for ascorbic acid content.

\section{Conclusion}

By considering the magnitude of heterosis obtained in the present study, three cross combinations viz. Solan Lalima x EC-1055, Solan Lalima x EC-1057 and Solan Lalima x EC-EC-1058 have recorded significant positive heterosis at $5 \%$ level of significance over better parent, mid parent and standard check for all the traits. These $F_{1}$ crosses as such can be brought under commercial cultivation after regional validation or can be exploited further by partitioning generations for trait specific crop improvement in Tomato. The study also suggests that hybrid breeding can be used efficiently to improve post harvest quality and nutritional value of tomato.

\section{REFERENCES}

Anita, S., Gautam, J.P.S., Upadhyay, M. and Joshi, A. (2005). Heterosis for yield and quality characters in tomato. Crop Research, 29(2): 285-287

Anonymous. (2014). Handbook of indian horticulture database, NHB, Gurgaon. Department of Agriculture and Cooperation, Ministry of Agriculture, Government of India, New Delhi, pp 48

De Candolle, A. (1886 reprint 1959). Origin of cultivated plants. Hafner Publishing Company, New York, 468 pp.

Droka, D., Kumar, R., Joshi, S. and Yadav, R.K. (2012). Genetic studies of quality traits in tomato (Solanum lycopersicum L.) under low temperature. Vegetable Science, 39 (2): 189-191

FAO. (1979). Recommended practices for the prevention of mycotoxins in food, feed, and their products. Food Agric Organ UN Rome, Italy, 51: 35-45

Garg, N. and Cheema, D.S. (2011). Assessment of fruit quality attributes of tomato hybrids involving ripening mutants under high temperature conditions. Scientia Horticulturae, 131: 29-38

Giovanelli, G., Lavelli, V., Peri, C, and Nobili, S. (1999). 
Variation in ripening. J Sci Food Agric., 79:1583-1588

Gomez, K.A. and Gomez, A.A. (1983). Statistical procedures for agricultural research. $2^{\text {nd }}$ ed., John Wiley and Sons, New York

Graca, A.J.P., Junior, A.T.A., Rodrigues, R., Goncalves, L.S.A., Sudre, C.P., Vivas, M. and Melo, P.C.T. (2015). Heterosis and combining ability of dual-purpose tomato hybrids developed to meet family farmers' needs in Brazil and Mozambique. Horticultura Brasileira, 33: 339-344

Hedrick, U.P. and Booth, N. (1907). Mendelian characters in tomato. Proceedings of American Society of Horticultural Sciences, 5: 19-23

Joshi, A., Thakur, M.C. and Kohli, U.K. (2005). Heterosis and combining ability for shelf life, whole fruit firmness and related traits in tomato. Indian Journal of Horticulture, 61(1): 33-36

Kumari, S. and Sharma, M.K. (2011). Exploitation of heterosis for yield and its contributing traits in tomato, Solanum lycopersicum L. International Journal of Farm Sciences, 1(2) :45-55

Mather, K. and Jinks, J.L. (1971). Biometrical genetics, 2nd ed. Chapman and Hall Ltd., London, UK.

Premalakshmi, V., Thangaraj, T., Veeraragathatham, D. and Arumugam, T. (2002). Hybrid vigour for yield and shelf life in tomato (Lycopersicon esculentum Mill.). South Indian Hort., 50: 360-369

Ramakrishnan K., Narayanan, P., Vasudevan, V., Muthuku- maran, G., and Antony, U. (2010). Nutrient composition of cultivated stevia leaves and the influence of polyphenols and plant pigments on sensory and antioxidant properties of leaf extracts. J Food Sci Technol., 47 (1): $27-33$

Ranganna, S. (1995). Handbook of analysis and quality control for fruit and vegetable products, 2 nd edition. Tata McGraw Hill, New Delhi

Reddy, V.V.D. and Reddy, B.M.M. (1994). Heterosis for fruit characters in tomato. J. Maharashtra Agric. Univ., 19: $312-314$

Rick, C.M. (1969). Origin of cultivated tomato, current status and the problem. International Botanical Congress, pp 180

Sharma, D. and Thakur, M.C. (2008). Evaluation of diallel progenies for yield and its contributing traits in tomato under mid hill conditions. Indian Journal of Horticulture, 65(3): 297-301

Shull, G.H. (1911). Experiments with maize. Bot Gaz., 52: 480-483

Singh, A., Gautam, J.P.S., Upadhyay, M. and Joshi, A. (2005). Heterosis for yield and quality characters in tomato. Crop Research, 29(2): 285-287

USDA Nutrient Data Bank [Online]. http:// www.nal.usda.gov/ [accessed may 2016]

Willcox, J.K., Catignani, G.L., Lazarus, S. (2003). Tomatoes and cardiovascular health. Critical Reviews on Food Science and Nutrition, 43 (1):18 